\title{
SITOTOKSISITAS KOMBINASI EKSTRAK PUSPA (Schiima wallichii) DA N KECAMBAH BROKOLI (Brassica olerasea) TERHADAP SEL KANKER PAYUDARA MCF-7
}

\author{
Ajeng Diantini, Maya Febriyanti, Melisa Intan Barliana, Rizky Abdulah \\ Fakultas Farmasi Universitas Padjadjaran
}

\begin{abstract}
Abstrak
Puspa (Schiima wallichii) diketahui memiliki aktivitas antikanker melalui mekanisme menginduksi apoptosis pada sel kanker payudara MCF-7, sedangkan kecambah brokoli (Brassica olerasea) dilaporkan dapat menghambat proliferasi sel-sel kanker kandung kemih dan prostat secara in vitro. Pada penelitian ini dilakukan pengujian sitotoksisitas kombinasi ekstrak puspa (EP) dan ekstrak kecambah brokoli (EKB) terhadap sel kanker payudara MCF-7. EP memberikan nilai $\mathrm{IC}_{50} 60,76 \mu \mathrm{g} / \mathrm{ml}$, sedangkan EKB tidak memberikan persentasi inhibisi lebih besar dari 50\% pada rentang konsentrasi uji. Sitotoksisitas kombinasi EP-EKB dengan perbandingan $\mathrm{IC}_{50}$ 1:2 memiliki nilai Indeks Kombinasi $<0,9$ menunjukkan bahwa kombinasi EP-EKB memberikan efek sinergisme.
\end{abstract}

Kata kunci :puspa, kecambah brokoli, sinergisme, MCF-7

\begin{abstract}
Puspa (Schiima wallichii) are known to have anticancer activity through a mechanism induces apoptosis in breast cancer cells MCF-7, while the broccoli sprouts (Brassica olerasea) has been reported inhibit the proliferation of cancer cells of bladder and prostate in vitro. In this study the cytotoxicity assay of combination puspa extract (EP) and broccoli sprout extract (EKB) against breast cancer cell line MCF-7 were evaluated. IC50value of EP were $60.76 \mathrm{ug} / \mathrm{ml}$, whereas EKB didn't give a percentage inhibition greater than $50 \%$ in the tested concentration range. Cytotoxicity assay of combination EP-EKB with IC 50 ratio of 1:2 showed higher cytotoxicity than EP or EKB alone in same concentration and given $C I$ (combination index) value $<0.9$, indicates that the combination of EP-EKB had synergism effect.
\end{abstract}

Keywords : puspa, broccoli sprout, synergism, MCF-7

\section{Pendahuluan}

Kanker payudara merupakan jenis kanker yang paling sering diderita oleh wanita dan menempati urutan pertama sebagai penyebab kematian pada wanita akibat kanker (Anonim, 2004). Pengobatan kanker payudara dengan agen kemoterapi masih terbatas karena masalah resistensi obat dan efek toksik pada jaringan normal yang mengarah ke imunosupresi dan kardiotoksisitas (Tyagi, et al., 2004). Oleh karena itu perlu dikembangkan alternatif lain untuk meningkatkan efisiensi terapi sekaligus mengurangi toksisitas terhadap sel-sel bukan kanker.

Penggunaan tumbuhan alami untuk keperluan pengobatan, hingga saat ini masih diminati sebagian besar penduduk di Indonesia sebagai pilihan pengobatan alternatif. Tumbuhan memiliki peran penting sebagai sumber senyawa antikanker yang efektif pada praktek klinis, seperti vinblastine, vincristine, derivat camptothecin, topotecan, irinotecan, dan etoposid, yang diisolasi atau berasal dari Catharanthus roseus G.Don. (Apocynaceae), Camptotheca acuminata Decne (Nyssaceae), 
Podofilum peltatum Linnaeus (Podophyllaceae) dan Taxus brevifolia Nutt. (Cragg, et al., 2005). Tanaman lain yang telah diteliti memiliki aktivitas antikanker adalah puspa (Schima wallichii) dan brokoli (Brassica olerasea).

Puspa merupakan tanaman yang tumbuh di sebagian besar wilayah Indonesia, tetapi pemanfaatannya saat ini terbatas pada batangnya, untuk dijadikan kayu, sedangkan daunnya menjadi pakan primata. Daun puspa mengandung senyawa bioaktif kaempferol-3O-rhamnoside yang memiliki aktivitas antikanker melalui mekanisme menginduksi apoptosis pada sel kanker payudara MCF-7. Hasil penelitian menunjukkan kaempferol-3-Orhamnoside menghambat proliferasi sel kanker payudara MCF-7 dan memicu apoptosis melalui caspase signaling cascade, yang meliputi caspase-9, caspase-3, dan PARP (Diantini, et al., 2012).

Saat ini kecambah brokoli juga menjadi perhatian para peneliti karena mengandung sulforaphane sepuluh kali lebih banyak dibandingkan brokoli dewasa. Kecambah brokoli telah dilaporkan dapat menghambat karsinogenesis kulit dan kandung kemih in vivo dan juga menghambat proliferasi sel-sel kanker kandung kemih dan prostat secara in vitro. Sifat antikanker dihasilkan mikronutrien aktif utama kecambah brokoli, sulforaphane, dengan mekanisme induksi apoptosis mitochondriamediated, induksi cycle arrest, penghambatan deacetylase histon (HDAC), induksi enzim fase 2 termasuk glutathione S-transferase (GST) dan kuinon oksidoreduktase 1 (NQO1). Selain itu, studi klinis dari Inggris mengusulkan bahwa kecambah brokoli juga berinteraksi dengan glutathione S-transferase mu 1 (GSTM1) genotipe untuk mengganggu jalur sinyal onkogenik (Abdulah, et al., 2009).

Kombinasi dari dua bahan alam untuk pengobatan kanker merupakan masalah yang menarik untuk dipelajari.

Salah satu model sel kanker yang dapat digunakan dalam pengujian obat terapi kanker payudara yaitu sel MCF-7 (Michigan Cancer Foundation-7). Sel MCF-7 memiliki beberapa karakteristik khusus yang sesuai, merujuk pada epitel payudara. Salah satu karakteristik khusus sel MCF-7 adalah kemampuan sel ini untuk membentuk estradiol dari estrogen melalui reseptor estrogen dalam sitoplasma sel. Hal ini membuat sel MCF-7 menjadi penerima estrogen (ER) positif dalam kontrol sel (ATCC, 2012).

Pada penelitian ini dilakukan pengujian untuk mengetahui sinergistitas sitotoksisitas kombinasi ekstrak puspa dan kecambah brokoli. Dalam penelitian ini sebagai alat uji digunakan galur sel kanker payudara yang umum digunakan dalam uji aktivitas antikanker secara in vitro, yaitu galur sel MCF-7.

\section{Bahan dan Metode \\ Bahan}

Bahan yang digunakan dalam penelitian ini terdiri atas :

1. Sel MCF-7 (sel kanker payudara manusia) ATCC cell lines HTB 22 koleksi Laboratorium Kultur Sel dan Sitogenetik Rumah Sakit Pendidikan Universitas Padjadjaran.

2. Bahan uji berupa ekstrak etanol daun puspa (EP )dan ekstrak air kecambah brokoli (EKB).

3. Bahan kimia yaitu: etanol $96 \%$ teknis, dimetilsulfoksida (DMSO, Sigma), medium kultur Rosewell Park Memorial Institute 1640 (RPMI 1640, Gibco), Fetal Bovine Serum (Gibco), tripsin (Sigma), Phosphate Buffer Saline (PBS, Gibco), dan Kit WST-8 (Dojindo).

\section{Alat}

Labu kultur jaringan $40 \mathrm{ml}$ (Tissue Culture Flask,Nunclon), pelat kultur jaringan 96 sumuran (Tissue CulturePlate 96 well, Nunclon), Laminar Air FlowBiological Safety Cabinet, inkubator seldengan aliran oksigen $95 \%$ dan $\mathrm{CO}_{2} 5 \%$,tangki nitrogen cair, oven, otoklaf, tabung 1,5 $\mathrm{ml}$ (EppendorfTM), pipet serologiksteril $2 \mathrm{ml}$ (Falcon), tabung dan alat sentrifuge (Falcon,Porta Centrifuge), mikropipet (EppendorfTM), ELISAplate reader (Stat Fx 2100), rotary evaporator dan freeze dryer.

\section{Metode}

\section{Pembuatan Ekstrak Puspa}


Daun puspa yang sudah dibersihkan diiris tipis-tipis dan dikeringkan, dimaserasi dalam etanol 96\% selama 3 x 24 jam. Ekstrak yang diperoleh dipekatkan dengan rotary vacuum evaporator sampai menjadi ekstrak kental.

\section{Pembuatan Serbuk Kecambah Brokoli}

Kecambah brokoli segar (300 gram) diblender dengan $250 \mathrm{ml}$ aquadest sehingga diperoleh ekstrak air kecambah brokoli sebanyak $300 \mathrm{ml}$. Kemudian ekstrak air dikeringkan menggunakan freeze dryer hingga diperoleh serbuk kering.

\section{Pembuatan Larutan Uji}

Ekstrak puspa dan ekstrak kecambah brokoli masing- masing ditimbang sebanyak 0,1 g, kemudian masing-masing dilarutkan dalam $1 \mathrm{ml}$ aqua bidestilata sehingga diperoleh konsentrasi larutan induk $100.000 \mu \mathrm{g} / \mathrm{ml}$, lalu diencerkan dengan penambahan medium sampai diperoleh bermacam-macam konsentrasi yaitu 1,$0 ; 2,0 ; 4,0 ; 8,0 ; 15,6 ; 31,2 ; 62,5$; dan $125 \mu \mathrm{g} / \mathrm{ml}$.

\section{Pengujian Sitotoksisitas Terhadap Sel MCF-7}

Pengujian sitotoksisitas dilakukan pada pelat 96 sumuran. Ke dalam tiap sumur dimasukkan suspensi sel dalam medium RPMI 1640 sebanyak $50 \mu$ l kemudian diinkubasi selama 24 jam dalam inkubator sel pada suhu $37^{\circ} \mathrm{C}$. Setelah 24 jam, ke dalam sumur uji dimasukkan $50 \mu 1$ larutan ekstrak sehingga diperoleh konsentrasi akhir 0,$5 ; 1,0 ; 2,0 ; 4,0 ; 8,0 ; 15,6 ; 31,2$; dan

$62,5 \mu \mathrm{g} / \mathrm{ml}$ kemudian diinkubasi kembali selama 24 jam dalam inkubator sel pada suhu $37^{\circ} \mathrm{C}$. Setelah perlakuan ditambahkan $10 \mu \mathrm{l}$ Kit WST-8 ke dalam tiap sumur kemudian diinkubasi kembali selama 4 jam pada suhu $37^{\circ} \mathrm{C}$ dalam inkubator sel sampai terbentuk kompleks formazan yang berwarna kuning. WST-8 [2-(2-methoxy-4-nitrophenyl)-3-(4-
nitrophenyl)-5-(2,4-disulfophenyl)-2Htetrazolium, monosodium salt] adalah garam tetrazolium yang menghasilkan formazan yang larut dalam air setelah direduksi oleh dehidrogenase.

Masukkan pelat kultur 96 sumuran ke dalam ELISA plate reader. Baca serapannya dengan ELISA plate reader pada panjang gelombang $450 \mathrm{~nm}$ dengan referensi $630 \mathrm{~nm}$. Persentase kematian sel MCF-7 dari larutan uji dihitung dengan rumus :

Dari pengujian aktivitas sitotoksik diperoleh $\mathrm{IC}_{50}$ masing-masing ekstrak.

\section{Pengujian Efek Kombinasi}

Untuk uji efek sitotoksik kombinasi ekstrak puspa dan kecambah brokoli dibuat seri konsentrasi berdasarkan perbandingan $\mathrm{IC}_{50}$ dengan cara pengenceran yang menggunakan media kultur RPMI 1640. Efek kombinasi dinyatakan dalam nilai Indeks Kombinasi (combination index).

\section{Perhitungan Statistik}

Indeks Kombinasi (combination index (CI)) secara luas digunakan untuk mengukur sinergisme obat berdasarkan efek obat multiple persamaan ChouTalalay (Chou TC and Talalay P, 1984). Dalam penelitian kami, nilai tersebut CI ditentukan untuk masing masing konsentrasi ekstrak puspa, ekstrak kecambah brokoli, dan kombinasi keduanya dalam uji sitotoksisitas. CI $<0,9$ menunjukkan sinergisme, $\mathrm{CI}=$ 0,9-1,10 menunjukkan interaksi aditif, dan $\quad \mathrm{CI}>\quad 1.10$ menunjukkan antagonisme [Zhu et al., 2010].

\section{Hasil dan Pembahasan \\ Sitotoksisitas EP dan EKB terhadap Sel Kanker Payudara MCF-7}

Tanaman yang dikonsumsi oleh primata merupakan sumber obat potensial untuk aplikasi dalam pengobatan dan pengelolaan penyakit manusia. Milton (1999) menyebutkan bahwa makanan secara rutin dikonsumsi oleh 
primata merupakan sumber heksosa, selulosa, hemiselulosa, zat pectic, vitamin $\mathrm{C}$, mineral, asam lemak esensial dan protein. Hal ini menunjukkan bahwa diet primata non-manusia mungkin merupakan bidang penelitian yang penting untuk kesehatan manusia (Milton et al., 1999). Dalam penelitian ini, diuji sitotoksisitas puspa (Schima walichii Korth). salah satu tanaman yang dikonsumsi primata dan secara luas ditemukan di daerah tropis Nepal, Sikkim, Assam, Myanmar, China Selatan, Semenanjung Melayu, Indonesia dan Filipina (Chalise, 2003).

Perlakuan sel MCF-7 dengan sampel uji EP menghasilkan grafik persen inhibisi proliferasi sel terhadap konsentrasi yang diperlihatkan pada Gambar 1. Senyawa aktif puspa yang telah ditelitimemiliki aktivitas sitotoksik adalah kaempferol-3-O-rhamnoside. Kaempferol-3-O-rhamnoside dapat memicu apoptosis melalui caspase signaling cascade pada sel kanker payudara MCF-7 (Diantini, et al., 2012). Dari penelitian ini diketahui bahwa EP memiliki nilai $\quad \mathrm{IC}_{50}$ $60.76 \mathrm{ug} / \mathrm{ml}$ terhadap sel kanker payudara MCF-7.

Kecambah brokoli diketahui memiliki kandungan sulforafan yang sangat tinggi. Aktivitas kemopreventif sulforafan mulai diteliti pada awal tahun 1990 dimana diketahui dapat menghambat induksi tumor oleh 7,12-dimethylbenz-(a)-anthraacene pada tikus (Zhang, et al., 1994). Sulforafan memiliki sifat antikanker dengan mekanisme induksi apoptosis mitochondria-mediated, induksi cycle arrest, penghambatan deacetylase histon (HDAC), induksi enzim fase 2 termasuk glutathione S-transferase (GST) dan kuinon oksidoreduktase 1 (NQO1). Selain itu, studi klinis dari Inggris mengusulkan bahwa kecambah brokoli juga berinteraksi dengan glutathione $\quad$ S-transferase- $\mu-1 \quad$ (GSTM1) genotipe untuk mengganggu jalur sinyal onkogenik (Abdulah, et al., 2009). Pada penelitian ini EKB memiliki aktivitas sitotoksik terhadap sel kanker payudara MCF-7 yang ditunjukan pada Gambar 2. Namun pada rentang konsentrasi uji, tidak diperoleh konsentrasi yang menghambat proliferasi sel lebih dari $50 \%$.

\section{Sitotoksisitas Kombinasi EP dan EKB}

Pada uji sitotoksisitas kombinasi EPEKB digunakan seri konsentrasi dengan perbandingan $\mathrm{IC}_{50} \mathrm{EP}$ dan $\mathrm{EKB} 1: 2$ dengan konsentrasi uji 0,$5 ; 1,0 ; 2,0 ; 4,0 ; 8,0 ; 15,6$; 31,2; dan $62,5 \mu \mathrm{g} / \mathrm{ml}$. Hasil perlakuan sel MCF-7 dengan ekstrak kombinasi EP-EKB ditunjukkan pada Gambar 3. Kombinasi EPEKB memberikan persen inhibisi proliferasi sel yang lebih besar dibandikan dengan EP dan EKB pada konsentrasi yang sama. Berdasarkan \% Inhibisi Proliferasi Sel EP, EKB, dan kombinasi EP-EKB dihitung nilai CI dengan persamaan Chou-Talalay. Nilai CI < 0,9 (Gambar 4) menujukkan bahwa kombinasi EP memberikan efek sinergisme pada rasio $\mathrm{IC}_{50} 1: 2$. 


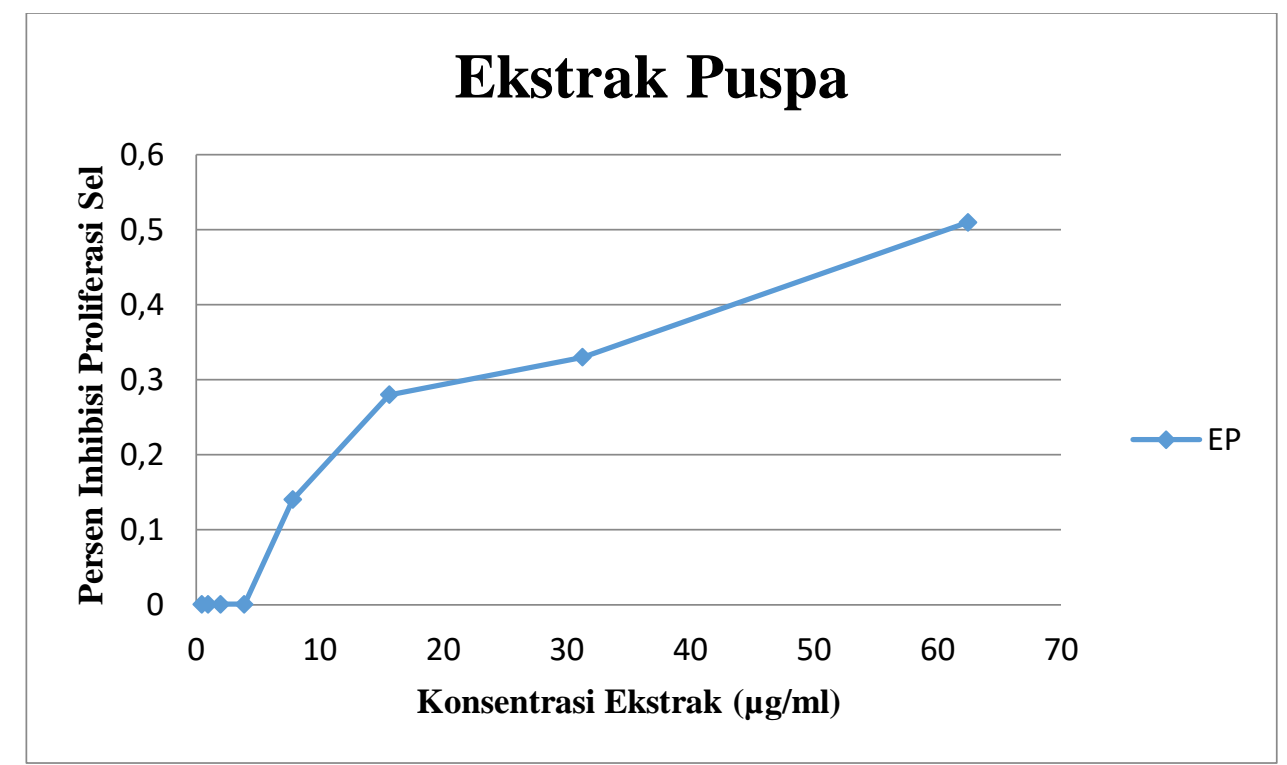

Gambar 1. Sitotoksisitas ekstrak daun puspa terhadap sel kanker payudara MCF-7

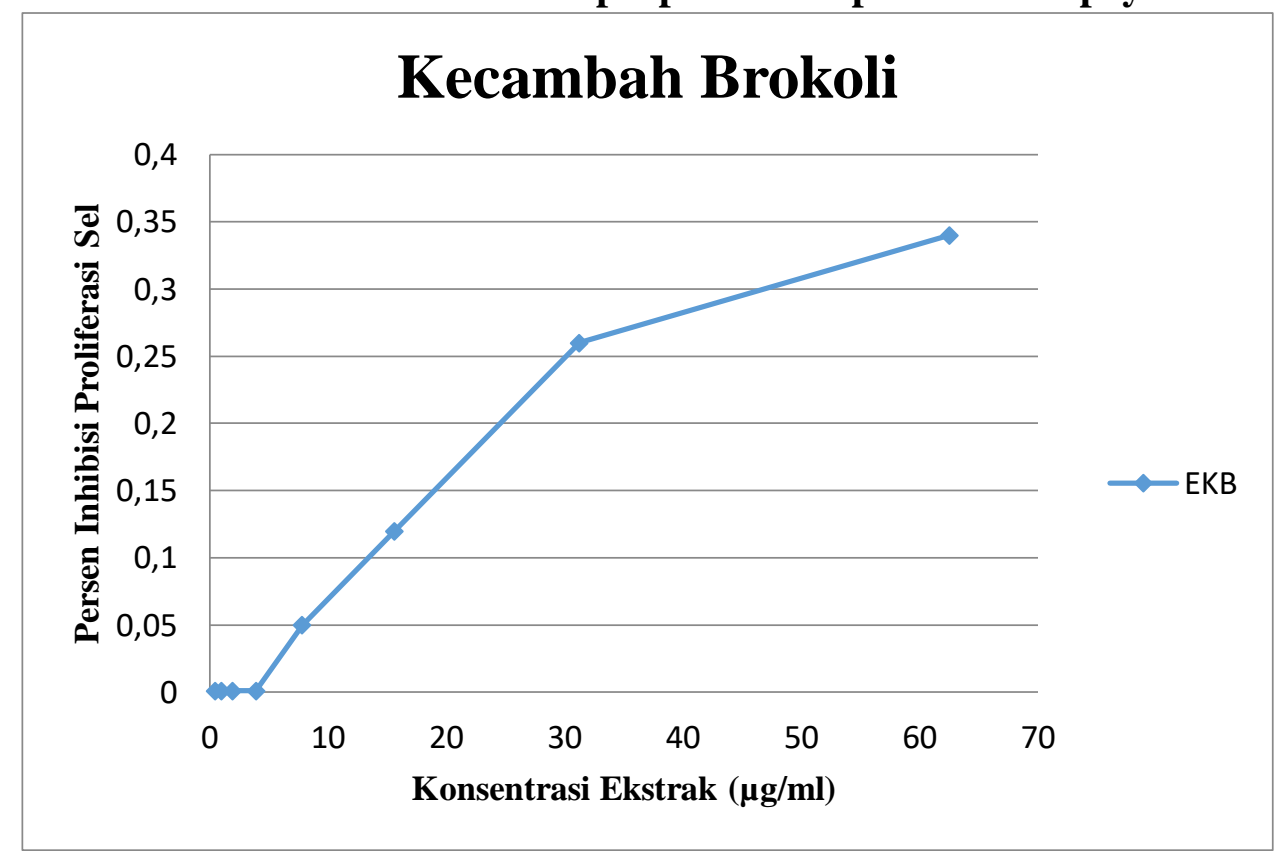

Gambar 2. Sitotoksisitas ekstrak kecambah brokoli terhadap sel kanker payudara MCF-7 


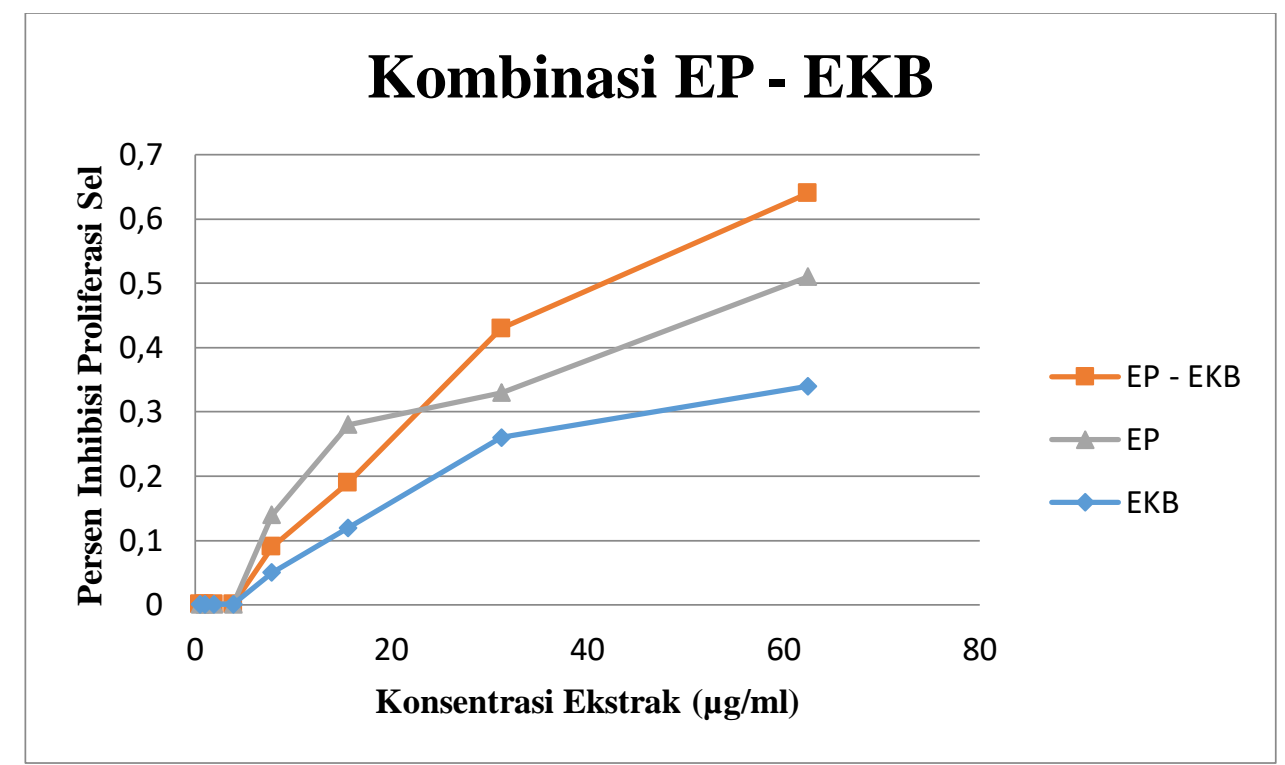

Gambar 3. Sitotoksisitas kombinasi ekstrak daun puspa dan ekstrak kecambah brokoli

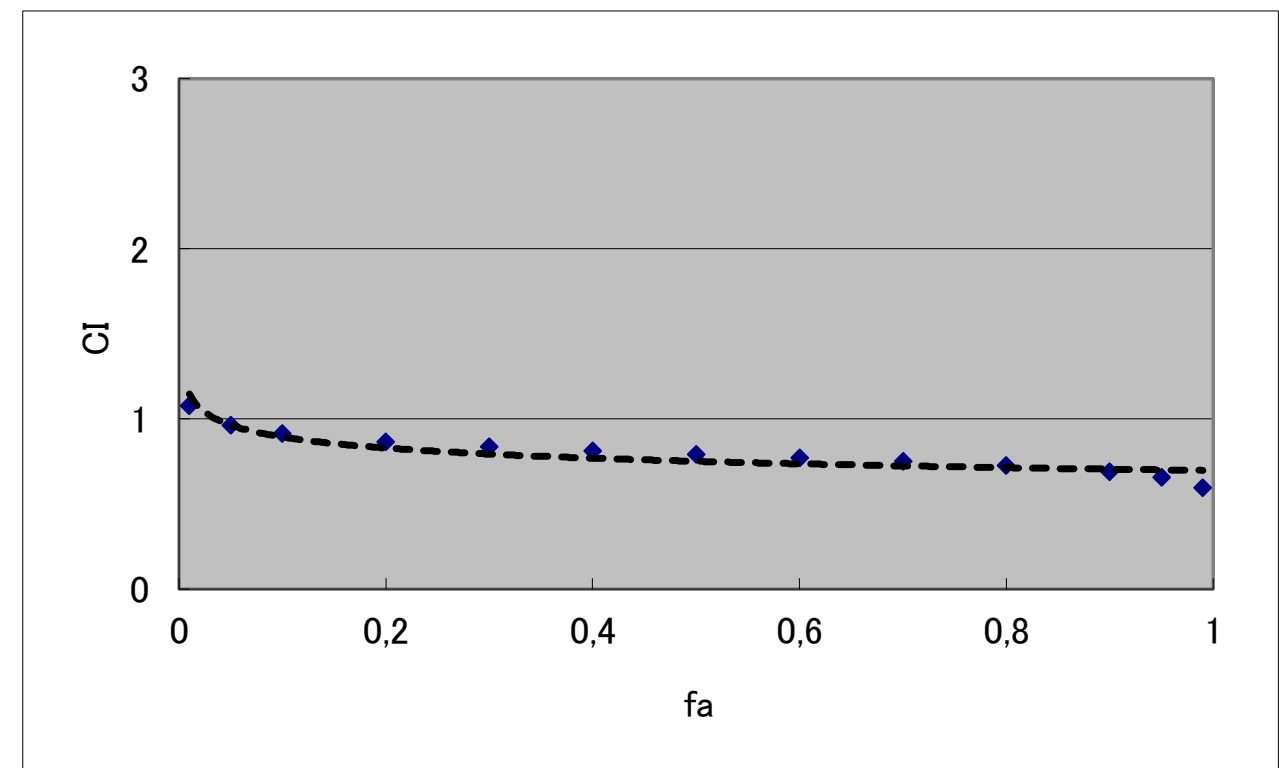

Gambar 4. Perhitungan persen inhibisi proliferasi berdasarkan persamaan Chou-Talalay

\section{Kesimpulan}

Penelitian ini menunjukkan bahwa kombinasi EP-EKB memberikan efek sitotoksik sinergis terhadap sel kanker MCF-7. Dengan demikian, kombinasi EPEKB potensial untuk dikembangkan sebagai terapi penyerta dalam terapi kanker.

\section{Daftar Pustaka}

Ajeng Diantini, Rizky Abdulah, Melisa Intan Barliana: Produksi TabletHerbal Terstandar Kombinasi Ekstrak Daun Puspa (Schima wallichii)dan Kecambah Brokoli (Brassica olerasea) sebagai Terapi Penyerta (Ajuvan) pada Kemoterapi Kanker Payudara,

Anonim. 2004. National cancer control programmes: Policies and managerial guidelines. 4th Edition. Geneva: World Health Organization, 9-61.

Chalise, MK. 2003. Assamese Macaques (Macaca assamensis) in Nepal. Primate Conservation 19: 99-107

Chou TC, Talalay P. 1984. Quantitative analysis of dose-effect relationships: the combined effects of multiple drugs or 
enzyme inhibitors. Adv Enzyme Regul, 22, $27-55$.

Milton K. $1999 . \quad$ Nutritional characteristics of wild primate foods: do the diets of our closest living relatives have lessons for us? Nutrition 15: 488-498

Tyagi AK, Agarwal C, Chan DCF, Agarwal R. 2004. Oncology Reports, 11, 493-499.

Zhang Y, Kensler TW, Cho CG, Posner GH, Talalay P. 1994. Anticarcinogenic activities of sulforaphane and structurally related synthetic norbornyl isothiocyanates. Proc Natl Acad Sci U S A, $91: 3147-50$.

Zhu H, Ding WJ, Wu R, Weng QJ, Lou JS, Jin RJ, Lu W. 2010. Synergistic anticancer activity by the combination of TRAIL/APO-2L and celastrol. Cancer Invest, 28, 23-32. 